\title{
PBXIP1 wt Allele
}

National Cancer Institute

\section{Source}

National Cancer Institute. PBXIP1 wt Allele. NCI Thesaurus. Code C104730.

Human PBXIP1 wild-type allele is located in the vicinity of $1 \mathrm{q} 21.3$ and is approximately 12 $\mathrm{kb}$ in length. This allele, which encodes pre-B-cell leukemia transcription factor-interacting protein 1 , is involved in the negative regulation of transcription factor activity. 